\title{
Early Childhood Education: Difficulties Creating and Changing Daily Practice
}

\author{
Sonia Kramer \\ Department of Education, Pontific Catholic University, Rio de Janeiro, Brazil \\ Email: sokramer@puc-rio.br \\ Received 7 February 2014; revised 7 March 2014; accepted 14 March 2014 \\ Copyright (C) 2014 by author and Scientific Research Publishing Inc. \\ This work is licensed under the Creative Commons Attribution International License (CC BY). \\ http://creativecommons.org/licenses/by/4.0/

(c) (i) Open Access

\section{Abstract}

This paper is based on research carried out with children and adults at early childhood education institutions in Rio de Janeiro, Brazil. The research goals were to identify interactions between adults and children and to rethink pedagogical practice. The theoretical-methodological framework was based on language and culture studies, the sociology of childhood and anthropology. After studying children and adults in different contexts and early childhood education public policies and practice, the results present challenges of changing and creating early education practices in difficult contexts, especially with regard to the creation and use of spaces intended for children. This is the focus of the text, which is structured in three sections. Section one presents the theoretical and methodological issues. The second section analyzes three case studies developed in public pre-schools situated in different cities in the state of Rio de Janeiro. Section three presents conclusions and priorities for intervention and change concerning children, adults and their interactions.

\section{Keywords}

Early Childhood Education, Daily Practice, Children and Adults Interactions, Educational Change

\section{Introduction}

This paper is based on research with children and adults at early childhood education institutions in Rio de Janeiro, Brazil. The research focused on micro and macro perspectives, studying both children and adults in different contexts and early childhood education public policies in the state of Rio de Janeiro. The research goals were to identify interactions between adults and children and to rethink pedagogical practice. The results invite researchers and educational administrators to meet the challenge of changing and creating early education practices in difficult contexts, especially with regard to the creation and use of spaces intended for children. This is 
the focus of the text.

According to the Brazilian Constitution, early childhood education is every child's right and a state obligation, implemented in "creches" (children aged up to 3 years); pre-schools (children aged 4 and 5); and pre-school classes in elementary schools (children aged 4 and 5). In the last twenty years, public policies for Early Childhood Education in Brazil have emphasized the right of children to activity and creation, which, however, has proven difficult in daily practice.

The following text is structured in three sections. Section one presents the theoretical and methodological issues. The second section analyzes three case studies developed in public pre-schools situated in different cities in the state of Rio de Janeiro. Section three presents conclusions and priorities for intervention and change concerning children, adults and their interactions.

\section{Children and Adults in Different Contexts: Theoretical and Methodological Issues}

The theoretical-methodological framework was based on language and culture studies, the sociology of childhood and anthropology, with the concern that "We do not ask nature and nature does not answer us. We ask ourselves and, in a certain way, we organize the observation or the experience to get the answer. When we study human beings, we search for and find signs all around and we engage in interpreting their meanings." (Bakhtin, 1992: p. 319).

Children are social actors who produce and are produced by culture, set in history and authors of their histories. Education is a "cultural action towards freedom" (Freire, 1975). The critical theory of culture and modernity (Benjamim, 1987) provides the theoretical basis for the conceptions of culture, childhood and education, where children are creative and critical (Benjamim, 2002); a conception of language in the core of humanities, where the object and the researcher are always subjects, implicated, situated (Bakhtin, 1992) and a conception of play as a cultural experience (Vigotski, 2009). Thus, childhood is a social and historical construct and children's interactions have ethical, cognitive, imaginative and emotional dimensions.

The research developed also considers Brazilian scientific production on education policies, teacher education and childhood education. Brazilian early childhood education researchers (Rosseti-Ferreira, 1998; Rocha, 1999; Kramer et al., 2009) have produced a body of work on this conception of childhood as a category and children as social actors and empirical individuals (Sarmento \& Pinto, 1997).

Concerning methodology, the researcher has to avoid both adult-centric postures (Corsaro, 1985; Corsaro, 2003; Corsaro, 1997) and ethnocentric postures (Da Matta, 1987). The researcher's work involves looking, listening and writing which are never neutral; a certain outlook on reality is implicit. Theory informs looking and listening and guides writing. Looking and listening are attitudes which the researcher develops during the fieldwork and are linked to choices, in which both the researcher's subjectivity and the theoretical background are present. To transform the exotic into the familiar and the familiar into the exotic is a goal (Da Matta, 1987). However, while in anthropological research on other cultures there is a physical distance between the exotic and the familiar, the researcher who researches his own environment investigates social distance and psychological distance, which is as hard as, if not harder than, physical distance (Velho, 1978). Researching in urban centers demands investigating wide social relationships and processes in which other actors are involved. That which the researcher sees might be familiar, but not known; that which he does not see might be exotic (beyond the common view), yet known.

Distancing ourselves we become perplexed at what is observed. The researcher questions his outlook, puts himself in the place of another, searches for the other's point of view in order to acknowledge and accept differences and to understand them. Similarly, in the sociology of childhood, the researcher avoids projecting his views upon the children or collecting from them the reflection of his prejudices; he tries to grasp the child's point of view and see the world with the eyes of a child, to abandon his adult viewpoint in order to understand.

The focus is the meaning of human action in a cultural context. Interpretative language studies (Bakhtin, 1992) guide the researcher to consider the place from which he observes, listens and asks. But it is impossible to thoroughly get to know another on his own terms; likewise, it is not possible to get to know oneself completely. Alterity is needed to understand others, to see oneself as another and a child as another. Doing research on children presupposes not concluding it. Conclusion for a human being is provided by the other, who sees one but 
whom one cannot see, the same way that one sees in others what they cannot see. What is or is not said, gestures and intonation need to be captured and understood. But it is not easy to exercise it in research: distancing oneself in order to see closer, this deduction of another's world thanks to the surplus of seeing. When one sees children playing, adults interacting with them and among themselves, one's place is socially and ideologically determined. How can I empathize with a teacher who puts children in "time out", sitting on the cold playground floor because they "don't know how to play”? I could understand such a view as a teacher, but my ethical commitment to the children puts me in their shoes. How can one be silent when faced with unacceptable adult attitudes and practices?

The distancing in order to understand means that the dialogic process of knowledge is an individual and a collective process. Knowing means acknowledging another's presence: grabbing becomes pointing because the baby learns from another to attribute such meaning (Vigotski, 2009). Comprehension is always active, it implies replies or counter-words. Research involves observing, listening to, understanding, analyzing discourses and interlocutions, observing child's play, narratives, dialogues among children and between children and adults. It is a matter of watching, and listening to, children and adults; observing interactions without forgoing the researcher's viewpoint, yet not being tempted to portray the individual observed based solely on this viewpoint.

\section{Researching Children and Adults in Different Contexts: Three Case Studies}

Research carried out in Brazil recognizes the effective expansion of Early Childhood Education in the public sphere, a right acquired in recent decades. But problems relating to quality are serious (Campos, Esposito, Bhering, Gimenes, \& Abuchaim, 2011; Campos, Fullgraf, \& Wiggers, 2006). Despite theoretical advances in the conception of childhood and of public policies aimed at improving conditions and quality (Brasil, 2009), the research indicates that the pedagogical work still emphasizes instruction, body control/posture, mechanical activities and not play (Kramer et al., 2009). Even when there is outdoor space in institutions, children spend most of the time in closed rooms with little room for expansion and creation (Tiriba, 2005; Toledo, 2014).

This text is the result of concurrent case studies in twenty-one institutions (seven "creches", seven pre-schools and seven schools) and the analysis of twenty Masters Theses and twelve PhD Dissertations identified in a survey made between 2004 and 2013 on Early Childhood policies and practices in the State of Rio de Janeiro. The text focuses on three of the pieces of research (Barbosa, 2004; Freire, 2004; Toledo, 2010) chosen because they are case studies made in public pre-schools with graduate teachers, because of the practices observed in most theses and dissertations, because of the way professionals use the physical space of the institutions and because of the limited opportunities for creating given to children, core issues for Early Childhood Education in Brazil. Barbosa and Freire developed their research in the City of Rio de Janeiro and Toledo in a city situated in Metropolitan Area; the three case studies were then developed in the State of Rio de Janeiro.

The methodological strategies were: observation and detailed description of children and adult interactions; individual and collective interviews with adults and children; interactions with cultural production by/for the children; photographs of spaces, objects and interactions. Socio-economic data and social and cultural conditions of the institutions were taken into account, while being aware that to compare results and to draw conclusions can at best only be partial and provisional approaches in the humanities. The case studies explicit the methodological and ethical challenges, the conclusions or questions. Research is concerned with (1) the situatedness of meaning and of development (2) the active, affective process of creation of meaning, and (3) the constitutive power of language (Gaskins, Miller, \& Corsaro, 1992: p. 9).

Barbosa observed the preschool for six months, twice a week. Each observation lasted about two hours and a half. Freire observed the preschool for six months: one month from Monday to Friday, four and a half hours a day and then for five months, three times a week. Toledo made observations during a period of eight months, once a week. As this preschool was two hours far from Rio de Janeiro, the periods of observation were longer (four to five hours). As well as this, Toledo observed the preschool for one whole week, from Monday to Friday, at the end of the year. The three researchers observed different days of the week at different times of day. The researchers recorded recurrent practices. These procedures aimed to guarantee that the data collected were representative of the practices. The time spent in each school and with each class was intended to allow the researchers to be accepted by both teacher and children. Thus, even though the presence of the researcher may have influenced the teacher's attitudes at first, over time the continuing presence of the researcher and the long period of observation tended to make the interactions between the children and adults as normal as possible. 


\section{1. "More Time for Class"}

This research sought to understand the interactions between children of 4 and 5 years of age and adults, understand how children use space, what they do, say, how they play, analyze planned time and the practices in a public full-time pre-school located in a large and beautiful public park. The case study showed an institution where instructional activities prevailed. In the words of one teacher: "we can't spend too much time eating, we need more time for classes ... If not, if we let them spend a lot of time at meals, there will be no time for classes, and we are a school. Otherwise are we here just to take care of them?" (Barbosa, 2004: p. 63).

Children are curious, they have vitality and attempt to resist the teacher's actions, which are repetitive and often without meaning or coherence.

"A boy brought a turtle to school. The teacher decides to change her planned activity based on the children's interest... asks what the turtle eats, how it walks and the children answer and talk. Then she says: let's compare the turtle to us. Does the turtle use the bathroom? The children reply No. Why? Because it's small... because it doesn't know how to go... The teacher says it's because children are animals who think and the Turtle doesn't think... After the turtle has been used to work on same-different, soft-hard, smooth-rough... the teacher tells them to ask different things. A boy wants to know if it can watch TV? Of Course! Is the enthusiastic response from children and the owner of the turtle. The teacher smiles, but does not take the question forward but passes on to another.” (Barbosa, 2004: p. 77).

At other times, the teacher takes into account the children's interest, in particular when they bring things for "show and tell" to school.

"A boy brought a newspaper story about sharks off the Brazilian coast. The teacher says that the story is interesting, passes it round to the children to look, starts talking about the article, highlights what she thinks important. 25 children are sitting in a circle. Talking at the same time. Many questions get lost in the middle of the explanations. [later] The teacher reads the report and asks questions: what is a hurricane? It's like "BayBlade" The teacher doesn't listen and says that it is a very strong wind. What is an earthquake? When the Earth shakes. What is panic? When we get scared ... For all the questions, the children have an answer, but at this point, many do not seem to be interested in the answer. The kids have already been sitting in a circle for over an hour. When they finish reading, the teacher proposes that the children do a drawing. After drawing, the kids return to the circle. The newspaper article is on the wall, a boy goes to look and comes back pretending to do a huge dive: I'm the hammerhead shark... and the circle becomes a great ocean. Some children go to the wall, look at a shark and then dive into the "sea" in imitation of the shark." (Barbosa, 2004: pp. 77-78).

Contradictions abound in practice: the curiosity of the children is confronted with the teacher's interest in asking rhetorical questions to teach content of dubious consistency. At another point, the children are sitting around the table coloring a drawing. They are talking about the Hulk. A girl asks: "Miss, will the Hulk come after us?" And the teacher replies: "this is not the time to talk about the Hulk, it's time to paint the drawing." (Barbosa, 2004: p. 84).

However, what we notice most is the fact that the space all around is not seen. Despite this pre-school being situated in a beautiful garden, there is no mention of it by the children or by the adults. In this aspect, the following situation was observed:

"What is this?, asks the teacher. A sticker! No, it's the yard! This! It's a map of the school that the Easter Bunny left for us, says the teacher. Children identify things in the playground; sports court, toys, trees. A boy points to the drawing of the building and says: hey, here's the school! Where?, asks the teacher. Here, the teacher points to the black gate and the boy says: it's the school gate.” (Barbosa, 2004: p. 70).

The school is therefore identified with the built-up space, closed in by the gate. It's as if the park were invisible or as if the school weren't there. Of course we cannot say that it amounts to confinement, but the institutional space is closed, hard, breathing little of the green of the trees, the waterfalls and the paths in the park. No curiosity? No desire to do things differently?

"In the playground, the teacher arranges the children sitting on the floor of the play area and from there they see a big bundle of red, blue and yellow cellophane inside the tunnel. Some get up and run to the tunnel, but the teacher says that we must follow the footprints indicated on a map [that she had shown to the children in the classroom]. But we've seen it already, we've seen it! The children follow the footprints without paying too much attention, because they are already looking at the colorful cellophane. The children return to the classroom with three large eggs with a note, singing: Easter Bunny, bringing me [Brazilian children's Easter song]...... The new 
note says the Easter Bunny left a gift. The children want to open it to see the present, but the teacher smiles and says they're just balls wrapped in cellophane. No, you can't open it. The children insist and the teacher shows them: it really is a ball, you can see, because the paper is transparent." (Barbosa, 2004: p. 78).

Why can't the children open the present? More than that, cultural practices (such as reading or telling and listening to stories) are marked for preparation and use, being moved from the scope of aesthetic enjoyment to that of learning, contributing little to the children's imagination. On another day, after telling the story of the goldfish, the teacher asks them what they want to be when they grow up.

"I want to know what you want to be when you grow up. The children start to talk: driver, police officer, vampire, caretaker, firefighter, invent a car that flies, doctor, veterinarian, football player, hairdresser, teacher. At the end the teacher asks: what did the goldfish want to be? The answer seems to have nothing to do with the story: grow up! The teacher repeats the question saying they have to say what happened in the story, and goes on to say: no, he wanted a clean river. The teacher goes over the story and they all talk about it. Then she tells the children to draw what they liked most in the story. In all the drawings the children show the goldfish in clean water.” (Barbosa, 2004: p. 94).

Situations like the one described above evoke social class symbols that the teacher seems to have little clarity or sensitivity about. It is worth noting that wanting to grow up and be a vampire did not get any comment from the teacher, unlike clean water which was shown as a (social? moral?) concept to be fixed. Thus, stereotypes and content which is of questionable appropriateness is overlaid on play and art work. Little emphasis on friendship, on discovery and creation, little or no joy are the tonic. Children are seen as empty vessels that need to be filled. The practices observed do not help the child to experience his childhood as culture. There's indifference as to what could be obtained in pedagogical terms by enjoying living in that space. Children and adults, attending the institution as students, parents, teachers, helpers, could be invited to create, explore, discover.

\section{2. "Dangerous. Better to Stay inside Here. Safer."}

This piece of research attempts to understand the relationships between teachers and children of four and five year, in a municipal school in the urban space of the city centre, observing whether and how cultural production around the school circulates inside the school and if is present in the work done with children. The school where the research was carried out is also located in a large square (Freire, 2004: p. 2008).

"7:10 in the morning. The sun is hot. The researcher looks for a shady spot, but it's almost impossible. She is walking across a huge green area, a square, which is located in the city center to reach the School, where she will do her fieldwork. She walks slowly. She looks at the cotias, gopher-like animals, hundreds of them, in groups dotted around. Scattered all over the square, cats, dozens, hundreds of them. On this walk she watches the people passing by. Different types, some walking, some running; still others sitting on the benches; groups of firefighters doing Physical Education (...) and right in the middle of the square a group of older ladies and gentlemen who are doing their daily exercises led by a teacher. The school is on this square area, with a gate that leads to the Street right in front of the Firehouse, where the children go in and there is an iron gate that comes out onto the green grass of the square, but that is permanently closed. The question is: why?” (Freire, 2004: pp. 14-15).

First observations already indicate, therefore, that the gate between the school and the Park would always be closed.

"Park. Children play and the researcher sits on a bench with the teacher. They talk ... She talks about the beauty of the city, throws fruit remains over the fence for the animals; cats and ducks come up (...) She speaks of the beauty of the city, how good it is, despite the violence, to live [in this city]. She says she lives in a neighborhood near the school, traditional in cultural terms, that she walks down the streets, knows almost everyone who walks there, that she loves working at this school because of the place. The "view is wonderful! It's beautiful, don't you think? Even more so, in the morning!" The researcher asks: "why don't you take the kids to play there a bit? Why not?" "Because the Director feels it would be better not to, it is dangerous." "Dangerous? Now in the morning? Why?" "There are a lot of people around, doing nothing. There is prostitution as well. Better to stay inside. Safer. And anyway, what they would do there, they can do here just as well.” (Freire, 2004: p. 101).

The beauty of the place, says the teacher, comes up against the ban imposed by the Director. The square-a large area in which the school is situated, is considered dangerous, full of strangers with whom children should not talk even when they are inside the wire fence that surrounds the school. When outdoors, they usually play in 
the little play park, which is situated inside the school grounds.

"Playground. 8:30 in the morning and it's sunny. Children are playing on the toys, running to and fro. The teacher is sitting reading a magazine. The children don't look, don't notice the movement, not the employee, nor the cotias. The (park) official then yells to the children: "good morning! "They, at that moment, look through the wire fence and shout in reply: "good morning". The teacher raises her eyes from the magazine and says: "I told you not to talk to strangers." But the children don't listen. They run to the wire, stand on the bench and join in the feeding of the cotias. They shout to the ones further away, saying they are "slowcoaches", they tell him to put out more food, interact in a cheerful and friendly way. When he is finished he says goodbye and "see you tomorrow"'. The children reply in chorus and go back to playing." (Freire, 2004: pp. 101-102).

Although the teacher follows the guidance of the Director to the letter, the research shows that she has an open, cheerful and receptive attitude. There is dialogue, she listens and a there is a feeling of happiness in many situations where we also notice the connection of other teachers with the children.

"The children played in the playground today, then went to the reading room. At 10:30 they arrived in the classroom. They had already had lunch, brushed their teeth and now they go to the circle. In an hour they will leave, but the teacher follows the daily plan and sings the good morning song, fills in the calendar, takes the roll-call and notes the time slot. Little conversation. A girl asks her to tell a story but she explains very politely and carefully that today they are late and they will have to do it tomorrow. She gives out paper for table activities: drawing with colored pencils, wax crayons, markers, modelling clay. Everybody takes turns to sit at all the tables. The teacher follows it all closely, affectionately, calling the children by name. They are at ease, moving from table to table and changing activities without being told to.” (Freire, 2004: p. 118).

In many instances there are issues related to space, coming in and out of school or the classrooms, opening and closing the gate. The events mentioned refer to this aspect, but many others bring space to stage center. It seems that the prohibition on leaving school for the square, imposed by the Director, has been made a silent issue by her: no questioning of the rule or any expression of a desire to leave the smaller school area was observed. It is not discussed, but the idea is there: we are in a beautiful open space, and we stay here inside trapped inside a fence that keeps us from going out together with the children, to take advantage of the open space and activities with the cultural and natural heritage that this area is intended for.

"Dining room. 7:30 h. Children have breakfast and talk excitedly. There is no sun, it's cold and a light rain is falling. The Physical Education teacher has not yet arrived. Two teachers talk about what to do with the kids. They hesitate between going to the playground with the rain or going straight to the classroom. (...) "So, what do you think? Let's go to the playground anyway." "It's not raining a lot and in the classroom it will be chaos!" "Yes, they are going to be agitated in the classroom with nothing to do until Physical Education. Let's go to the playground at least until 08:15 $\mathrm{h}$. "So come on! The sand is wet and the toys too. The children seem to enjoy the idea and go to play. After a few minutes the rain is falling harder and children, obeying their teachers, run inside. One of the teachers goes to the reading room to get a film (...). The children are running riot. There was no playground but we're going to have a film! They talk a lot and discuss what film they are going to see, but the film didn't come. There was no alternative, each teacher took her class and led them to the classroom.” (Freire, 2004: p. 121).

On rainy days, the children can't go to the playground, they get more agitated, they want to run, to be free. But many schools don't even have a playground, which makes the desire to go out even more accentuated. At this school, relations between teachers and children are ambiguous: conversations, respect and affection coexist with rigid routines. The children are cheerful, open and friendly. The school does not take the children out, does not explore the cultural and natural heritage, which are also absent in the work they do. The surroundings-a square, immense, beautiful, open to the city centre, is regarded as dangerous. There is danger from outside, say the adults. But I do believe that there is danger on the inside: the danger of the same tedious routines and classes and a lack of courage to interact, to create, to talk about fear or to change.

\section{3. "You Have Lost the Right"}

The objective of the third piece of research work analyzed (Toledo, 2010) was to find out about the relationship between children and nature in a public school in a town in the Metropolitan Area of Rio de Janeiro. A class of 4 year old children and open events were observed (founder's day fete, a treasure hunt and a workshop with the children). The research showed that Early Childhood Education is designed to prepare children for Elementary 
School; playing is a secondary issue. The school was nominated for the research work by the Secretariat of Education because of its privileged open physical space: located in a Square with a large playground, land, trees, grass, playground with toys, outdoor all-weather sports court and covered courts, its classrooms are spacious, well lit and well ventilated. But this space and the presence of nature at the school does not guarantee that the children have contact with them.

"[In the classroom] The children play at tables, with plasticine, lego and puzzles. The teacher, at her desk, prepares gouache paints. While the children play, she calls them one by one to do the "some work". She doesn't tell the children what is going to happen [a bonfire, painted with the palm of their hand]. Put your hands like this, with fingers closed. The teacher shows her hand palm up. The child imitates. The teacher paints the child's palm. Now turn your hand so [palm down] and open your fingers. The child obeys. The teacher holds the child's hand and presses it firmly against the paper. Now take your "work", and put it over there [on the classroom floor with the others] and go to the bathroom and wash your hands. The teacher does this one by one with all the children. A series of paintings all alike, hands stamped in orange paint on the classroom floor. Lunchtime: the class goes downstairs, has lunch and returns to the room. The same activity continues: the entire process is repeated, in the same way, with all the kids. This time the teacher paints the hand of each child with brown paint and presses against the paper twice to represent the wood of fire.” (Toledo, 2010: p. 45).

Lots of the "work" doesn't make sense to the children. The school's institutional model prevails, favoring individual activities, containment of the body, few relationships among children. The irritation of adults was also observed in various situations. At another time, the teacher berates the child: You knew how to do your name and now you don't know any more?! It's laziness, that's what it is! You will only go down for lunch if you do your name! (Toledo, 2010: p. 47).

"Two classes [children of 4] sitting on the floor while the teachers dress up the playground for the party, hanging colored stenciled drawings by children which the teachers have cut, pasted on cd's and tied with string. The children start to get impatient and restless, get up, talk, play. The teachers tell them: will you stop? Sit Down! How annoying, can't you see we're trying to get the party ready? Some children are reprimanded. After scolding a girl several times, the teacher takes her by the arm, leads to the other side of the playground and leaves her sitting alone on one of the concrete benches. Another girl shouts out: "You've lost the right?". The children sat watching the teachers decorating the playground for about forty-five minutes.” (Toledo, 2010: p. 50).

It is worth explaining that the children in Brazilian schools often use this expression "you've lost the right" reflecting the teachers' use it as a sign of punishment, as a warning or reprimand. The curtailment of creation and inventiveness in children also appeared in the everyday life of this Early Childhood Education school:

"[In the classroom] The mimeographed drawing looks like a clown holding several balloons, each with a letter inside. The children have to identify the letters that make up their name and paint the corresponding balloons. The teacher scolds a boy by taking the crayons out of his hand: "Why did you take another color to color the balloons? You have to use the same color in all the balloons!” (Toledo, 2010: p. 54).

Although the school offers music lessons, the creative dimension is not present as is shown in the two events transcribed below. At first, the children are seated in chairs, listening to the music that they are going to present to parents at the school.

"[to the researcher] "I'm glad you came to see. I was giving the children a good rehearsal, because they are useless!" [to the children] "I want to see who's going to sing nicely." The children sing louder, almost shouting. The teacher is happy. "Congratulations on your beautiful little voices!" But she gets angry when the children clap, because they should do so only when she says. A girl is reprimanded, and has to stand next to the teacher." (Toledo, 2010: p. 58).

"Whoever talks will sit on the cold floor. Leave the velcro on your sneakers alone! Who is this naughty child? I think she's never worn a sneaker before! You can stand right here next to me! I'd like to see you play with your velcro now!", says the music teacher (Toledo, 2010: p. 60).

Harsh words, the gruff manner of the teachers, are directed at them constantly, even at holiday times, when one might expect a relaxed atmosphere. The children have no right (to be children): no right to laugh, joke, celebrate, worry about others. In other words, they seem to have lost the right to be children, or rather, to be human.

\section{Conclusions and Proposals}

During the research process, I had to deal with different theoretical and practical implications. Conflicts and 
challenges were always there. I faced issues concerning the research, but also aspects concerning pedagogic work and curriculum; the distance between school contexts and Brazilian educational laws was an ongoing concern; the ethical and cultural aspects underlying the interactions between children and adults were also constant concerns. This paper offers an opportunity to present the research and share the ideas, methodological challenges and difficulties that we faced and that we have had to deal with.

There are Early Childhood Education schools using buildings that were not purpose-built, merely adapted to meet student demand. Many have appropriate classrooms and spaces, but this does not guarantee proper use. Although many institutions have outdoor spaces and are located in a region where there is sunshine all year round, children spend most of their time inside closed rooms.

The movement of children within the spaces is regulated by forming lines. If they don't obey, the children are warned or punished. Songs are used to control, achieve results, command actions and postures which are deemed correct. Children are left alone or are supervised. There is little relationship between the knowledge they bring and what the teachers propose for the group. Creating is not valued: a standardized aesthetic prevails in children's drawings and projects in the classrooms (murals, boards with children's names for the roll-call, calendars). Notions of right and wrong exist for art and knowledge, understood as what was taught or resulted from questions made by the teachers. Literacy activities emphasize copying and mechanical repetition. There are few social and cultural practices for reading and writing which involve meaningfulness and creation.

In the games played by the children it is common to have rules established by the teacher (the number of children; what may or may not be done). But in those few free moments that the children have in the playground, without the intervention of adults, children's cultures seem to express themselves in games and inventions.

The results of the research show that the theoretical achievements, which have been present for at least twenty years in the legal documentation in force in Brazil, are not implemented in practice. What are the possible causes for these problems? Why is it that research findings, the achievements of social movements and changes in public policy documents do not affect practice? Unlike other countries, relations between academic production and public policies are difficult in Brazil, even in other school segments. Four elements can help us to understand this lag.

Firstly, it is important to stress that we are dealing here with relations between federal government and municipal policies. Changes in the federal public policy come up against poor working conditions in terms of salaries, career plans and number of children per class in schools, preschools and "creches", since these aspects are defined by each municipality (Kramer, 1995).

On the other hand, early childhood education is the responsability of municipal policies and, even though the federal law should be respected, the interference of local politicians in decisions means that many managers (administrators, directors, supervisors) are named without public examination, and with little or no training in the educational area. Also the criteria defined in tendering procedures for teachers are municipal decision: the municipalities in the case studies analyzed in this text do not require that teachers have higher education, although this is a requirement stipulated in federal legislation (Kramer et al., 2005).

A third aspect to be considered concerns the training of teachers (teacher education). This is a sociological and anthropological matter. Teacher training projects exist in Brazil, in fact there are quite a number of them, but they need to overcome the precarious scientific and cultural background of the teachers, which happens for historical reasons: the teachers themselves have studied at a school which has been seeking to improve its quality for at least three decades. Training the trainers is the central question that arises when looking at how to reverse the lag between changes in policies and the difficulty of change in practices.

Last but not least, one must take into account the school and teaching models that have historically prevailed in Brazil—and that have influenced early childhood education curriculum — where the teacher's role is foccused on transmission and where the use of didactic materials prevails over natural, cultural and artistic heritage and experience (Kramer, Nunes, \& Carvalho, 2013). This reinforces the need for the training of teachers and administrators to be developed as both scientific and cultural training leading towards emancipation, reflection and autonomy.

Thus, it is our responsibility to guarantee teachers and school administrators training, believing that:

1) Early Childhood Education aims to fit children into the social and cultural world, inviting them to play, expressing themselves and expanding their language, having pleasure in learning, solidarity and respect for the rights of children, just as they are, social and cultural actors.

2) All children are entitled to create, to express themselves through actions and movements, to be curious, to 
get knowledge, to increase their cultural universe and socio-cultural diversity, with receptivity to, and acceptance of, the differences encountered.

3) It is fundamental that adults act ethically, with accountability, autonomy and cooperation. In no event may acts be accepted that poke fun, humiliate or express prejudices.

4) The Early Childhood Education curriculum must ensure that there are cultural experiences which bring together scientific and cultural knowledge with the learning resulting from children's experiences, taking as a reference the child, its uniqueness, interests and curiosity.

5) Language and play are the center of the curriculum of Early Childhood Education. Language encourages the development of narrative and the telling of the stories they have experienced; while play is the experience of culture and a privileged way of expression for the child which occurs in spontaneous and planned situations, with and without adult intervention.

6) To encourage reading and writing, Early Childhood Education should expand the aesthetic and expressive experiences with music, plastic arts, cinema, photography, dance, drama, children's literature, amongst various textual, oral and written types of support and genres.

Reading, writing, and Early Childhood Education are linked to the world of knowledge and recognition of the other. In this context, it is worth asking and stating: why are so many professionals afraid to encourage a creative access to reading and writing? Have they forgotten that education must be the practice of freedom (Freire, 1975 ) and that we learn to read and write to be free? The contexts surveyed indicate that the paths of change to be followed go through training strategies (teacher education) bringing back real life stories, so the stories can be reendowed with meaning and the practices transformed.

\section{References}

Bakhtin, M. (1992). Estética da criação verbal. São Paulo: Martins Fontes.

Barbosa, S. N. F. (2004). Nas tramas do cotidiano: adultos e crianças construindo a educação infantil. Master Thesis, Rio de Janeiro: PUC-Rio.

Benjamim, W. (1987). Obras escolhidas II: Rua de mão única. São Paulo: Brasiliense.

Benjamim, W. (2002). Reflexões: A criança, o brinquedo, a educação. São Paulo: Duas Cidades, No. 34.

Brasil (2009). Resolução Conselho Nacional de Educação e Câmara de Educação Básica 5/2009, estabelece as Diretrizes Curriculares Nacionais da Educação Infantil.

http://portal.mec.gov.br/index.php?option=com_content\&view=article\&id=13684\%3Aresolucoes-ceb-2009\&catid=323\% 3Aorgaos-vinculados\&Itemid=866

Campos, M. M., Esposito, Y., Bhering, E. B., Gimenes, N., \& Abuchaim, B. (2011). A qualidade da educação infantil: Um estudo em seis capitais brasileiras. Cadernos de Pesquisa, 41, 20-54. http://dx.doi.org/10.1590/S0100-15742011000100003

Campos, M. M., Fullgraf, J., \& Wiggers, V. (2006). A qualidade da educação infantil brasileira: Alguns resultados de pesquisa. Cadernos de Pesquisa, 36, 87-128. http://dx.doi.org/10.1590/S0100-15742006000100005

Corsaro, W. (1985). Friendship and Peer Culture in the Early Years. Norwood: Ablex.

Corsaro, W. (1997). The sociology of Childhood. Thousand Oaks, CA: Pine Forge Press.

Corsaro, W. (2003). We're Friends, Right?: Children's Use of Access Rituals in a Nursery School. Washington, DC: Joseph Henry Press.

Da Matta, R. (1987). Relativizando: Uma introdução à antropologia social. Rio de Janeiro: Rocco.

Freire, E. F. (2004). E lá fora o que é que tem? Educação Infantil e produção cultural no centro da cidade do Rio de Janeiro. Ph.D. Dissertation, Rio de Janeiro: PUC-Rio.

Freire, P. (1975). Cultural Action for Freedom. Cambridge, MA: Harvard Educational Review.

Gaskins, S., Miller, P., \& Corsaro, W. (1992). Theoretical and Methodological Perspectives in the Interpretative Study of Children. In: W. Corsaro, \& P. Miller (Eds.), Interpretative Approach to Children's Socialization (pp. 5-23). San Francisco, CA: Jossey Bass Publishers.

Kramer, S. (1995). Alfabetização, leitura e escrita: Formação de professores em curso. São Paulo: Ática.

Kramer, S., et al. (2005). Profissionais de educação infantil: Gestão e formação. São Paulo: Ática.

Kramer, S., et al. (2009). Retratos de um desafio: Crianças e adultos na educação infantil. São Paulo: Ática.

Kramer, S., Nunes, M. F., \& Carvalho, M. C. (2013). Educação Infantil: Formação e responsabilidade. Campinas: Papirus. 
Rocha, E. C. (1999). A pesquisa em educação infantil no Brasil: trajetória recente e perspectivas de consolidação de uma pedagogia. Florianópolis: UFSC.

Rosseti-Ferreira, C., et al. (1998). Promoção da qualidade e avaliação na educação infantil: Uma experiência. Cadernos de Pesquisa, 105, 52-77.

Sarmento, M. J., \& Pinto, M. J. (1997). As crianças: Contextos e identidades. Braga: Minho.

Tiriba, L. (2005). Crianças, natureza e educação infantil. Ph. D. Dissertation, Rio de Janeiro: PUC-Rio.

Toledo, M. L. P. B. (2010). Relações e concepções de crianças com/sobre a natureza. Rio de Janeiro. Master Thesis, Rio de Janeiro: PUC-Rio.

Toledo, M. L. P. B. (2014). Entre o exposto e o escondido, marcas e vestígios de pátios de escolas de Educaçao Infantil. Ph.D. Dissertation, Rio de Janeiro: PUC-Rio.

Velho, G. (1978). Observando o familiar. In: Nunes, E. O. (Org.), A aventura sociológica: Objetividade, paixão, improviso e método na pesquisa social (pp. 36-46). Rio de Janeiro: Zahar.

Vigotski, L. S. (2009). Imaginação e criação na infância. São Paulo: Ática. 